\title{
Çocuklarda Postpnömonik Ampiyem: Retrospektif, Tek Merkez Çalışması
}

Postpneumonic Empyema in Children: Retrospective, Single Institution Study

\section{Feride MEHMETOĞLU ${ }^{1}$, Emine KINACI ${ }^{2}$, Mensur SÜER ${ }^{3}$}

\author{
1. Çocuk Cerrahisi Kliniği, Dörtçelik Çocuk Hastanesi, Bursa \\ 2. Çocuk Hastalıkları Kliniği, Dörtçelik Çocuk Hastanesi, Bursa \\ 3. Radyoloji Kliniği, Dörtçelik Çocuk Hastanesi, Bursa
}

\section{ÖZET}

Amaç: Pulmoner enfeksiyonlara sekonder olarak gelişen ampiyemlerin teşhis ve tedavisi için farkl yaklaşımlar önerilmektedir. Bu çalışmanın amacı ampiyemli çocukların teşhis ve tedavi uygulamasındaki klinik tecrübelerimizin sunulmasıdır.

Materyal ve Metod: 1993-2016 yullar arasinda bir kamu hastanesi çocuk cerrahi kliniğinde ampiyem nedeni ile toraks drenajı uygulanarak tedavi edilen çocukların klinik verileri geriye dönük olarak incelendi. Hastalar interkostal toraks tüpü drenajı gerekliliği açısından; fizik muayene, ayakta ön arka ve/veya lateral dekübit akciğer grafisi, serum laboratuar testleri, tantsal torasentez ve plevra sıvısı çalışmaları ile değerlendirildi.

Bulgular: Toplam 70 hasta; 39 erkek ve 31 klz, ortalama yaş 6.9 yll, (5 gün-17 yıl) tedavi edildi. 55 (\% 78.5) hasta, toraks ultrasonografisi (US) ile takip edildi. En slk izole edilen bakteriler Staphylococcus aureus ve Streptococcus pneumoniae idi. 8 hastaya sıvının lokulasyonu veya teknik nedenlerden dolayı iki kez tüp takıldı. Toplam 70 hastaya 81 toraks tübü yerleştirildi. Tüpler 3-41 gün içinde çıkarıldı (ortalama 11 gün). 21 hastada değişen derecelerde plevral kalınlaşma, 6 hastada pnömotosel nedeni ile pnömotoraks gelişti. Risk ve sinırlı olanaklar nedeni ile fibrinolitik ajanlar ve dekortikasyon uygulanmadi. Aileler bu konuda bilgilendirildi. Plevral kalınlaşmalar çoğunlukla klinik düzelmeyi takiben azalarak 10-90 gün (ortalama 20 gün) içinde kayboldu ve akciğerler tamamen re-expanse oldular.

Sonuç: Post pnömonik ampiyemlerde; X-ray, laboratuvar testleri ve US teşhis ve takip açısından yeterli olmuştur. Tedavi sistemik antibiyotikler, kapalı intercostal göğüs tübü drenajı ve göğüs fizyoterapisi kombine edilerek başarıly yapılmıştır. Iyyileşme süresi uzun bulunmakla beraber, bu temel tedavi öncelikli olarak tercih edilmelidir.

Anahtar Kelimeler: pnömoni; çocuk; plevral effüzyon; ampiyem; göğ̈̈s tübü

\section{İletişim Bilgileri}

Sorumlu Yazar: Op. Dr. Feride MEHMETOĞLU

Yazışma Adresi: Dörtçelik Çocuk Hastanesi Ertuğrulköy, Bursa, Türkiye

E-posta: mferide@yahoo.com

Tel: +90 (224) 2752000

Makale Geliş Tarihi: 03.04.2017

Makale Kabul Tarihi: 17.08.2017

DOI: http://dx.doi.org/10.16948/zktipb.303774

\section{ABSTRACT}

Objective: Different approaches have been proposed for the diagnosis and treatment of empyema secondary due to pulmonary infections. The aim of this study was to present our experience of diagnostic and therapeutic procedures in children with empyema.

Material and Methods: Clinical data of children with empyema that were treated with chest drainage in a public hospital pediatric surgery clinic between 1993 and 2016 were reviewed retrospectively. Patients were evaluated in terms of intercostal chest tube drainage with physical examination, erect anteroposterior and/or lateral decubitus chest radiograph, serum laboratory tests, diagnostic thoracentesis and pleural fluid studies.

Results: In a total of 70 patients; 39 males and 31 females with a mean age of 6.9 years (5 days-17 years) were treated. $55(78.5 \%)$ patients were monitored with chest ultrasonography (US). Most common isolated bacteria were Staphylococcus aureus and Streptococcus pneumoniae. 8 patients underwent re-intubation due to the loculation of fluid or technical reasons. A total of 81 chest tubes were inserted in 70 patients. The tubes were removed within 3-41 days (mean 11 days). 21 patients had varying degrees of pleural thickening, pneumothorax developed due to pneumatoceles in 6 patients. Because of the risks and limited facilities, fibrinolytic agents and decortication were not applied. Families were informed about it. Pleural thickenings decreased mostly following the clinical improvement in 10-90 days (mean 20 days) and lungs re-expanded completely.

Conclusion: X-ray, laboratory tests and US were sufficient for the diagnosis and follow-up of postpneumonic empyema. Treatment was successfully done by combining systemic antibiotics, closed intercostal chest tube drainage and chest physiotherapy. Although there is a long recovery time, this essential treatment should be considered as a primary choice.

Keywords: pneumonia; child; pleural effusion; empyema; chest tube 


\section{GİRIŞ}

Plevral boşlukta biriken pürülan sıvının ampiyeme neden olduğu ve eksternal drenaj gerektirdiği antik zamanlardan beri bilinmektedir. Hipokrat, Aegina'lı Paul ve Fabricius ampiyem tedavisi için gerekli olan drenajın ne zaman ve nasıl olması gerektiği sorusuna yanıt aramışlardır (1). Günümüzde halen yaygın olarak uygulanan kapalı toraks drenajı ile tedavi ise ilk olarak 1918 y1lında Evart Graham'in “erken açık drenajın pnömotoraks ve kollaps nedeni ile yüksek mortaliteye neden olduğunu" sunması ile uygulanmaya başlanılmıştır. Antibiyotiklerin tedaviye girmesinden bu yana ampiyemlerin tedavisinde güçlü bir antibiyotik tedavisi bir numaraya yerleşmiştir, ancak uygulanacak cerrahinin tipi ve zamanlaması konusunda değişik görüssler mevcuttur (2). Antibiyotik ile beraber uygulanacak olan; torasentez ile veya toraks tüpü ile drenaj, fibrinolitik tedavi, torakoskopik debridman, torakotomi ile dekortikasyon gibi diğer tedavi seçeneklerinin uygulanması konusunda halen bir standart oluşmamıştır (3). Üçüncü basamak sağlık hizmeti veren spesifik çocuk hastanelerinde dahi, enfeksiyon sonrası gelişen efüzyonlara yönelik tedavi uygulamaları yayınlanmış ve iyi araştırılmış uygulama k1lavuzlarına uymamaktadır. Hastanelere göre tedavi şemaları değişmektedir (4-6). Bu çalışmada pnömoni sonrası ampiyem gelișen hastalarda kliniğimizde uygulanan yöntemler sunulmuştur.

\section{GEREÇ ve YÖNTEM}

Geriye dönük olarak yapılan çalışmaya 1993-2016 y1lları arasında 23 y1llık bir sürede bir çocuk hastanesinde pnömoni sonrası gelişen ampiyem nedeni ile kapalı toraks drenaj1 (KTD) uygulanarak tedavi edilen hastalar alındi. Malignensi, tbc, travma, şilotoraks, hastane kaynaklı pnömoni gibi nedenler ile gelişen plevral effüzyon veya pnömotoraks gelişen hastalar çalışmaya dahil edilmedi. Hastalar interkostal toraks tüpü drenajı gerekliliği açısından; fizik muayene, AP ve/veya lateral dekübit akciğer grafisi, serum laboratuar testleri, tanısal torasentez ile alınan plevra sıvısı çalışmaları ile değerlendirildi. Hastalar, hastanenin çocuk doktoru tarafından çocuk cerrahisi konsültasyonu yapılarak veya cerrahi görüş için dış merkezlerden yönlendirilmişlerdi. Toraks drenaj1 tek çocuk cerrahı tarafından yapılmıştı. Hastalar cerrahi veya çocuk enfeksiyon kliniklerinde yatırılarak takip edilmiş, antibiyotik tedavisi çocuk uzmanı tarafından düzenlenmişti. Bazı vakalarda, torasentezler farklı zamanlarda ve lokalizasyonlarda tekrarlanmıștı. Bu süre içinde bilgisayarlı tomografi (BT) merkezimizde olmaması nedeni ile yapılamamıştı, ancak 55 hasta toraks ultrasonografisi (US) ile takip edilmişti.

\section{BULGULAR}

23 yıllık sürede yaş ortalaması 6.9 yıl (5 gün-17 y1l) olan toplam 70 hasta kamuya ait bir çocuk hastanesinde tedavi edildi. Hastaların 39'u erkek (\% 55.7 ) ve 31'i kız (\% 44.3 ) idi. Yaş ve cinsiyet dağılımı Tablo 1'de gösterilmiştir. Hastaların tümü hastaneye ateş, öksürük, takipne, dispne ve ağrı şikayetleri ile başvurmuştu. Poliklinikte 14 hastada $(\% 20)$ ve klinikte 56 hastada $(\% 80)$ çekilen akciğer grafilerinde pnömoni ve plevral efüzyon saptanan hastalarda ilgili çocuk hastalıkları uzmanı tarafindan çocuk cerrahisi görüşü için yönlendirilmişti. 23 y1lda 70 olgu; y1llık ortalama olgu sayısı 3 olup en çok 10 olgu 2002 yılında tedavi edilmiştir. Yıllık vaka sayısı 2 defa üst seviyelere çıkmasına rağmen, olgu sayıları yıllar içinde azalmıştır. Hastaların yıllara göre dağılımı Şekil 1'de gösterilmiştir. Drenaj öncesi 65 olguda (\%93) üst ve alt solunum yolu enfeksiyonu nedeni ile bir veya birden fazla kür antibiyotik tedavisi uygulanmıștı. Hastaların tümü interkostal toraks tüpü ile drenajın gerekliliği açısından; fizik muayene, ayakta antero posterior 70 hasta $(\% 100)$ ve/veya lateral dekübit akciğer grafisi 20 hasta $(\% 28)$, serum laboratuar testleri, tanısal torasentez ve plevra sıvısı çalışmaları ile değerlendirilmişlerdi. 55 olgu (\%78.5) toraks US ile takip edilmişti. Bazı vakalarda, torasentezler farklı zamanlarda ve interkostal aralıklardan tekrarlanmıştı. $\mathrm{Bu}$ serideki hiçbir hastada tedavi amaçlı torasentez yapılmamıştı.

Tablo 1: Hastaların yaş ve cinsiyet dağılımı.
\begin{tabular}{|l|l|l|l|}
\hline \multicolumn{1}{|c|}{ Yaş (yıl) } & \multicolumn{2}{|c|}{ Cinsiyet } & \multicolumn{1}{c|}{$\mathbf{n}(\%)$} \\
\hline & \multicolumn{1}{|c|}{ Erkek (\%) } & \multicolumn{1}{c|}{ Kız (\%) } & \\
\hline $0-1$ yaş & $4(5.71)$ & $3(4.29)$ & $7(10.0)$ \\
\hline $1-5$ yaş & $13(18.57)$ & $12(17.14)$ & $25(35.71)$ \\
\hline $6-12$ yaş & $16(22.86)$ & $10(14.29)$ & $26(37.14)$ \\
\hline $12-17$ yaş & $6(8.57)$ & $6(8.57)$ & $12(17.15)$ \\
\hline Toplam & $39(55.71)$ & $31(44.29)$ & 70 \\
\hline
\end{tabular}

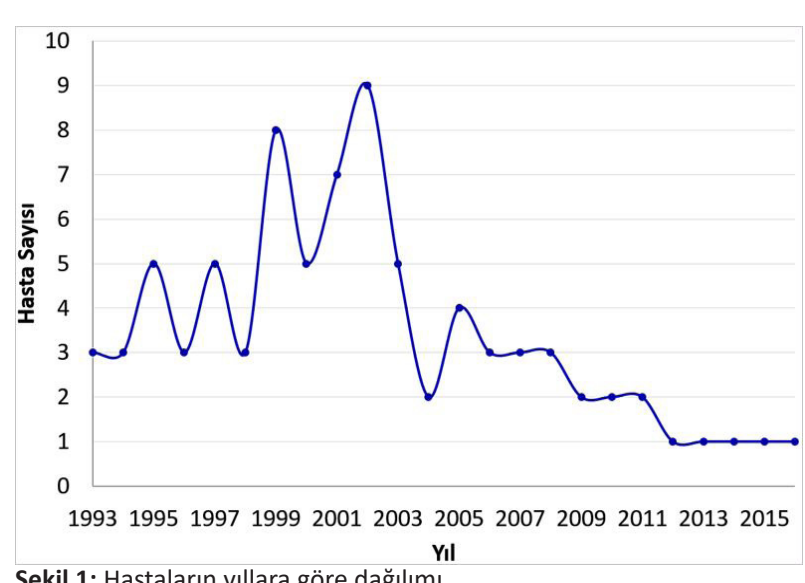

Şekil 1: Hastaların yıllara göre dağııımı. 
Hastaların tümünde torasentez sıvısından kültür yapılmıştı, ancak 37 olgunun (\%53) kültürlerinde üreme olmuştu. En sik izole edilen bakteriler Staphylococcus aureus ve Streptococcus pneumonia olup antibiyotik tedavisi çocuk uzmanı tarafından düzenlenmişti.

Torasentez ile alınan sivilar Light kriterlerine göre değerlendirilerek; sıvının makroskobik görünümü, X-ray bulguları ve kan C-reaktif protein (CRP) düzeyi, kan lökosit düzeyi (WBC), sedimentasyon hizına göre tüp torakostomi drenaj gerekliliği ve uygulanma kararı alınmıştı. 43 hastaya eksudatif fazda ve 27 hastaya fibrinopürülan fazda drenaj uygulanmıştı. 8 hastaya sıvının lokülasyonu veya teknik nedenlerden dolay1 ikinci kez tüp takılmıştı. Drenaj uygulamas1 11 hastaya (\% 16) lokal anestezi ile, 59 hastaya $(\% 84)$ ise genel anestezi altında yapılmışt1. 70 olguda 81 tüp torakostomi uygulanmış olup; 48'i (\% 59.3 ) sağ tarafta, 30’u (\% 37.0 ) sol tarafta ve 3'ü ise bilateral (\% 3.7$)$ idi (Şekil 2).

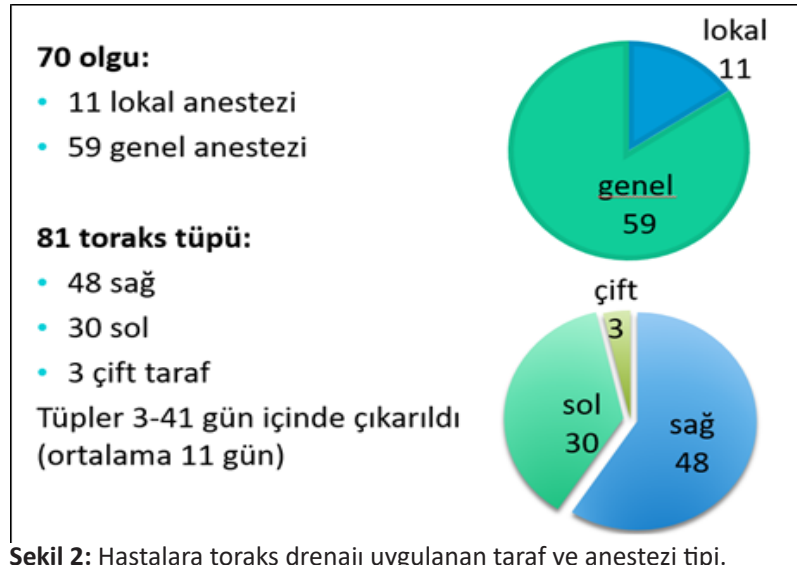

Toraks drenaj tüpleri 3-41 gün içinde çıkarılmiştı (ortalama 11 gün). 21 hastada değişen derecelerde plevral kalınlaşma, 6 hastada pnömatosel nedeni ile pnömotoraks gelişmişti. Plevral kalınlaşmaların tümü 6-17 yaş aralığındaki olgularda gelișmiști. Plevral kalınlaşmalar çoğunlukla klinik düzelmeyi takiben azalarak ortalama 20 gün (10-90 gün) içinde kaybolmuştu, akciğerler tamamen re-expanse olmuştu (Re$\operatorname{sim} 1,2,3,4)$. Fibrinolitik ajanlar veya dekortikasyon uygulanmamıştı, aileler tüm tedavi ve girişim süreçlerinde bilgilendirilmişlerdi.

Yatış süreleri ortalama 27 gün (15-50 gün) olan hastalar tüp drenajı çekildikten ve antibiyoterapisi tamamlandıktan sonra klinik olarak bulguları düzelince taburcu edilmișlerdi. Plevral kalınlaşmaları olan olgular haftalık olarak ayaktan takip edildiler. Gögüs fizyoterapisi (solunum egzersizleri, balon şişirme veya tri-flo cihazı ile) plevral kalınlaşma kaybolana kadar devam edilmişti. 23 yıllık sürede hiçbir hastada nüks görülmemiştir.

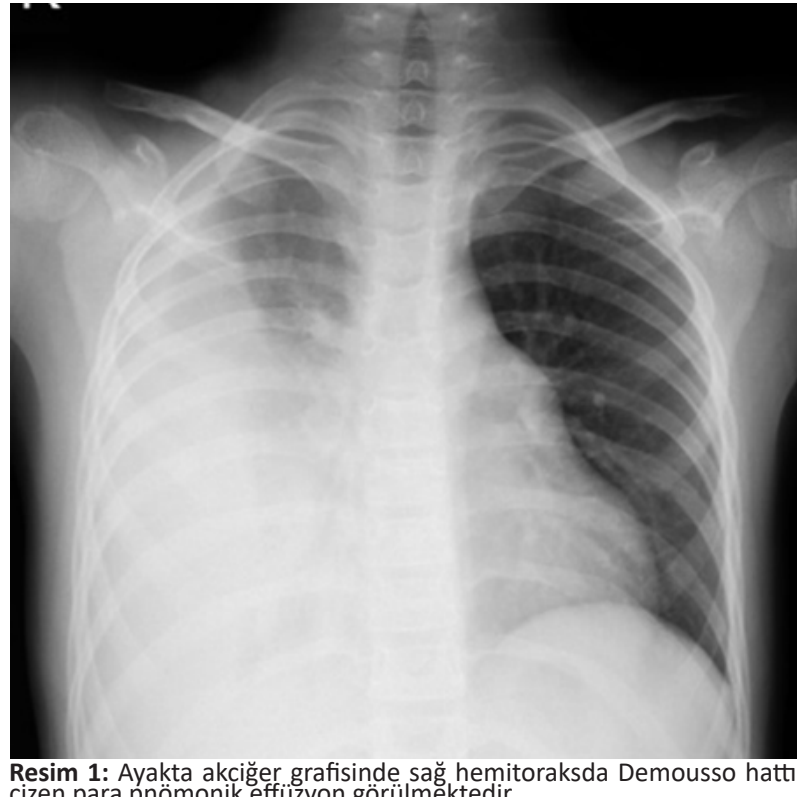
çizen para pnömonik effüzyon görülmektedir.

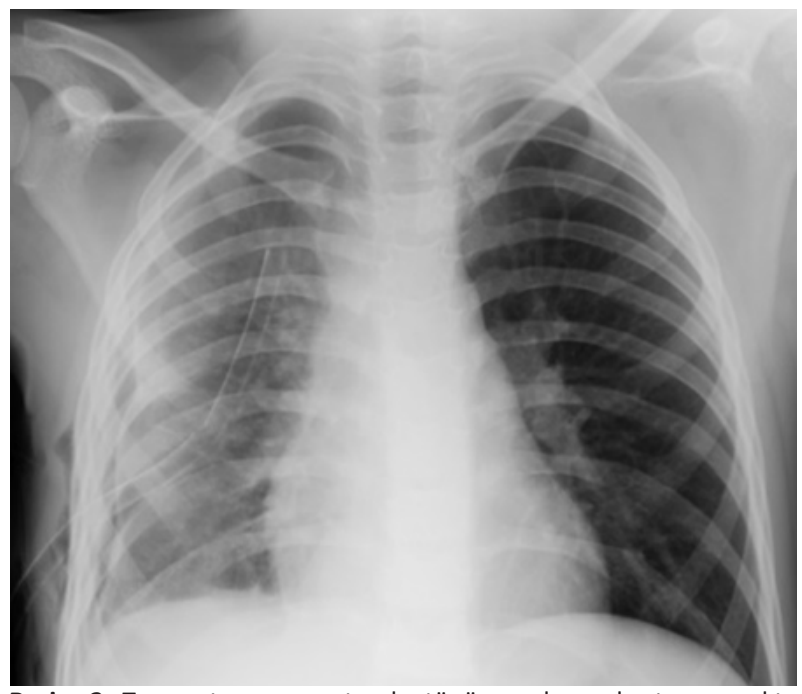

Resim 2: Torasentez sonrası toraks tüpü uygulanan hastanın ayakta grafisinde tüm effüzyonun boşaldığı görülmektir.

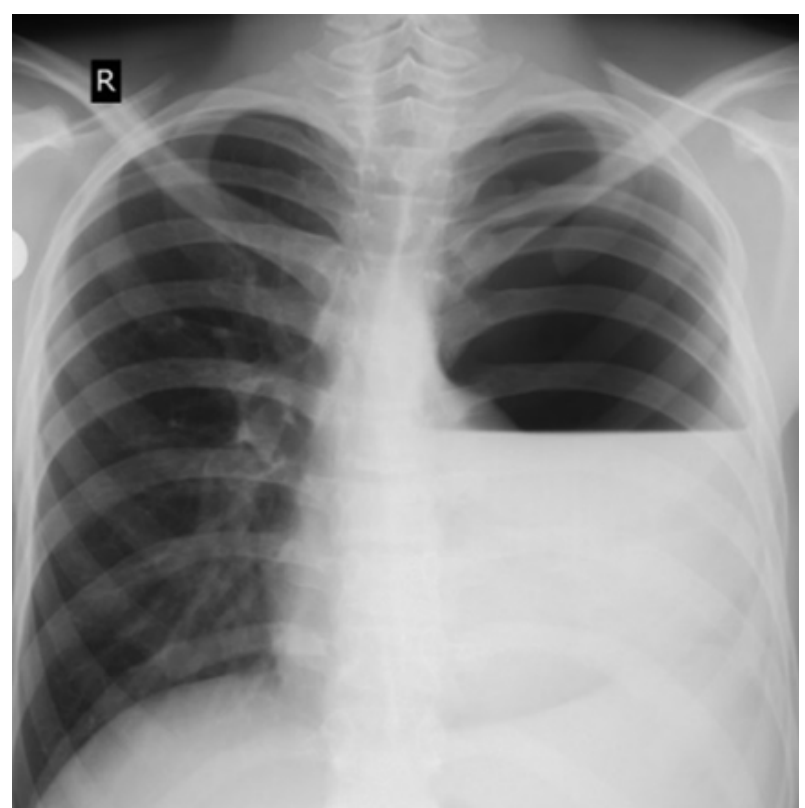

Resim 3: Pnömotosel gelişen bir olguda sol hemitoraks içinde hava sıvı seviyesi oluşturan effüzyon görülmektedir. 


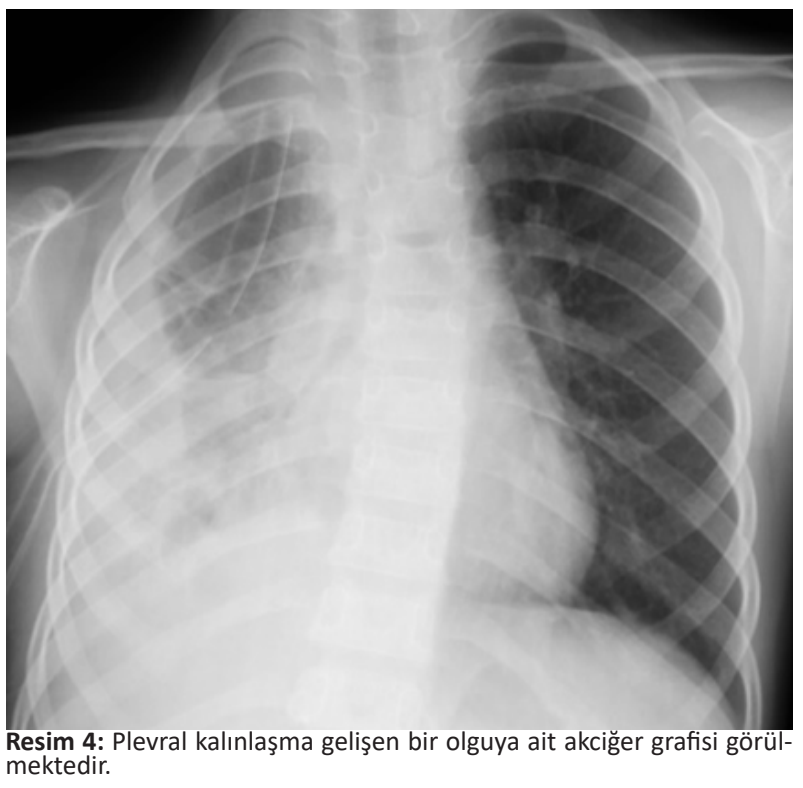

\section{TARTIŞMA}

Parapnömonik effüzyonlara bağlı ampiemler klasik olarak üç evrede gelișir: Eksüdatif evrede (komplike olmayan); plevral boşlukta biriken sivı steril, $\mathrm{pH}$ normal, laktat dehidrogenaz $(\mathrm{LDH})<1000 \mathrm{IU}$ dir. Fibrinoprulan evrede (komplike veya ampiem); siv1 prulan, fibrin depozisyonu ile septasyon ve lokulasyonlar meydana gelir, $\mathrm{pH}<7.2$ LDH siklikla $>1000$ IU' dir. Organize (kronik) evrede ise plevral kaviteye fibroblastların infiltrasyonu ile ince fibrin mebranlar kalınlaşarak akciğer ekspansiyonu engeller (7).

Plevral efüzyonların tanısında klinik bulgular ve solunum seslerinin oskültasyonu ne kadar önemli ise aynı şekilde akciğer grafisi, pnömoni ve buna bağlı gelişen effüzyonların teşhis ve takibinde son derece önemlidir $(8,9)$. US ve CT, akciğer filminde görülen opasitenin sıv1 olup olmadığı, miktarı ve lokulasyonu göstermesi açısından yararlı olduğu gibi US eșliğinde sıvının drenajı açısından da faydalıdır (10). US kolay ve non invazif olması nedeni ile öncelikli olarak tercih edilmelidir. CT alttaki akciğer parenkimini göstermesi açısından yararlıdır, ancak sedasyon gerektirmesi ve radyasyon riski nedeni ile komplike vakalarda tercih edilmelidir $(9,11)$. Tsujimoto ve ark.ları yetişkin hastalarda yapılan bir çalışmada plevra yaprakları arasındaki plevral sıvının CT ile ölçülmesi ile torasenteze gerek kalmadan komplike effüzyonların basit effüzyondan ayırıcı tanısının yapılabileceğini belirtmişlerdir (12). Serimizdeki tüm hastaların teşhis, tedavi ve gelişen komplikasyonların takibi laboratuvar tetkikleri, akciğer grafisi ve ultrasonografi ile yapılmıştır. Merkezimizde olmadığı için hiçbir hastaya CT yapılamamıştır. Klinik, US ve X-ray ile plevral kolleksiyonun miktar ve içeriğine göre takip yeterli görülmesi nedeniyle CT için hiçbir hastanın dıș merkezlere sevkine gerek görülmemiștir. Akciğer grafisinde ve ultrasonografide saptanan effüzyonlarda sıvının yapısını tetkik edebilmek ve görmek için torasentez gerekir, ancak teşhis amaçlı torasentez kararı effüzyonun miktarı ve hastaların bulgularına göre yapılmalıdır (11). Torasentez ile alınan plevral sıvının teşhis ve sinıflaması için Light sınıflaması standart olarak kabul edilmektedir (13). Aspire edilen siv1 Light kriterleri ile değerlendirilerek tedavide izlenecek yol belirlenir. $\mathrm{Bu}$ seride ele alınan hastaların tümünde drenaj kararı alınmasında plevral sıvının değerlendirilmesi etkili olmuştur. Teşhis amaçlı torasenteze ek olarak tedavi amaçlı erken dönem effüzyonların tekrarlayan torasentezler ile boşaltılmasına yönelik literatürde farklı yaklaşımlar mevcuttur $(9,10,14)$. Ancak çocuk yaş grubu için bunun travmatik olacağı ve tedavi süresini uzatacağı için klinik yaklaşım olarak tercih edilmemiştir. Torasentez sonrası drenaj gerekli görülen olgularda lokal veya genel aneztezi ile tüp torakostomi yapılarak kapalı su altı drenajına alınmıştır.

Pneumoni ve buna bağlı parapnömonik effüzyonlara sebep olan organizmaların türü, ülkelerin gelişmişlik düzeyine ve hastaların yaşına göre değişmektedir (11). Bu çalışmadaki olguların ancak yarısında (\% 53) kültürlerde üreme gösterilebilmiștir. Her yaşta en çok üreyen mikroorganizmalar Staphylococcus aureus ve Streptococcus pneumonia idi. Hastaların yaklaş1k \% 90'ında antibiyotik tedavisi dış merkezde başlanmıştı. Bazı hastalara aynı merkez veya birkaç farklı merkezde birden fazla kür antibiyoterapi uygulanmıștı. Bu nedenle bütün kültürlerde üreme olmadığ 1 düşünülmektedir.

Ampiem tedavisinde amaç antibiyotikler ile plevral boşluktaki enfeksiyonun tedavi edilmesi, pürülan sıvının drene edilmesi ile akciğerin tekrar ekspanse olmasını sağlamaktır (15). Etkili bir antibiyotik tedavisi pnömoni ve buna bağlı gelişen effüzyonların tedavisinde temel esastır (10). Uygulanacak antibiyotiğin süresi için literatürde belli bir takvim yoktur (11). Olgularımızda antibiyotik tedavisi ilgili çocuk uzmanı tarafından düzenlenmiştir. Antibiyotik tedavisi intravenöz olarak başlanmış, hastanın klinik ve laboratuvar bulgularına göre oral yolla devam edilmiştir.

Hastanın yaşı, kliniği ve ameliyathanenin uygunluk koşullarına göre lokal veya genel anestezi ile tüp torakostomi uygulanmıştır. Tüp torakostomi uygulamak için son yıllarda kullanımı artan pigtail kateterler, İngiliz Toraks Birliği ve Amerikan Enfeksiyon Hastalıkları Birliği tarafindan önerilmektedir $(9,16)$. Torakostomi tüpü olarak hastanın yaşına uygun çapta aspirasyon kateteri veya standart toraks tüpü kullanıldı. 
Genel olarak orta aksiller hattan 6-7 interkostal aralıktan tüp torakostomi takılırken, bazı olgularda sıvının lokülasyonuna göre sıvı aspire edilen bölgeden de drenaj uygulanmıştı. Her yaştaki hastalar tüp torakostomi drenajını iyi tolere etmişlerdi, tüp takılması ile ağrı şikayetleri takıldıktan sonraki 1-2 gün içinde tamamen geçmişti. Toraks tüpleri; drene edilen sıvının sıfırlanması, tüp içi sıvıda ossilasyon olmamas1, X- ray' de akciğerin ekspanse olması ve sinüsün açılması, ateş ve lökostozun gerilemesi sonrası çıkarılmışlardı.

Çocukluk çağında teşhis veya tedavi amaçlı uygulanan radyasyon özellikle meme, gonad ve tiroid dokusunda kanser riskini arttırmaktadır (17). Yapılan bir çalışmada tüp çıkarıldıktan sonra çekilen filmlerin tedavi planını değiştirmediği saptanmıştır (8). Bundan dolayı tüp öncesi ve sonrası takiplerde akciğer grafísi çekilmesi için hastanın bulgularına göre karar verilmiştir, ultrasonografi ile sıvı artış veya azalış durumuna göre takip ve tedavi uygulanmıştır. Ultrasonografik bulgular ile klinik bulguların örtüşmediği durumlarda gerekli görüldükçe akciğer grafisi çekilmiştir. Kontrol grafileri standart bir şemaya göre değil; hastanın klini$\breve{g i}$, drene edilen sıvının miktarı ve ossilasyon durumuna göre radyasyon çekincesi nedeni ile sadece gerekli durumlarda çekilmiştir. Tüp torakostomi çıkarıldıktan sonra kontrol X-ray görülmüştür. Plevral kalınlaşmalar kaybolana kadar hasta poliklinik takibinde tutulmuştur.

Plevral kalınlaşmaların küçük çocuklarda ve infantlarda kesinlikle dekortikasyon gerektirmeden uzun sürede hasar bırakmadan kaybolduğu rapor edilmiştir (18). Plevral kalınlaşmaların etkin bir tedavi ile operasyona gerek kalmadan düzeldiği Celayir ve ark.larının çalışmasında da gösterilmiştir (3). Miu ve ark. plevral kalınlaşmaların büyük çoğunluğunun birkaç ay içinde kaybolduğunu, akciğer grafilerinin düzeldiğini rapor etmişlerdir (11). Ampiem hastalıklarında $\mathrm{X}$ - ray'in düzelmesinin 12 ayı bile bulabileceği rapor edilmiştir (9). Bu serideki hastalarda en uzun 90 gün içinde klinik bulguların düzelmesini takiben plevral kalınlaşmalar kaybolmuştur, X-ray bulguları düzelmiştir. Drenaj sonrası taburcu edilmiş klinik bulgusu olmayan ayaktan takipli hastalarımızda X-ray bulgusu olan plevral kalınlaşmalar için antibiyoterapi dahi gerekmediği gibi cerrahi girişim düşünülmemiştir. $\mathrm{Bu}$ süre içerisinde solunum fizyoterapisi, derin soluk alıp verme egzersizleri dışında başka bir tedavi uygulanmamıştır.

Ampiem ile gelişen kalın fibrin ve eksüdanın drenaj ile boşaltılamadığı durumlarda eksüda içine verilen enzimlerin lokülasyonu gevşeterek drene olmasını öneren yayınlar yeni değil$\operatorname{dir}(19)$.
Günümüzde, fibrinolizis yapan bu ajanların hastane yatış süresini kısalttığ 1 ve cerrahi debridman kadar etkili olduğu için kullanılmasını öneren çalışmalar mevcuttur $(9,20,21) . \mathrm{Bu}$ amaçla streptokinase, urokinase, DNase, tPA gibi enzimler farklı doz ve tedavi planı ile kullanılmaktadır. Ancak fibrinolitik tedavinin dezavantajları olarak pahalı olması, uygulamada ağr1 olması, henüz standart bir tedavi șeması oluşmaması, uygulama için tüp torakostomi gerektirmesi ve bazı olgularda tedaviye yanıt alınamayıp cerrahi debridman gerektirmesi şeklinde sıralanabilir. Ayrıca entübasyon gerektiren bronkospazm, alerjik reaksiyonlar, kanama ve hemotoraks, ciddi risk oluşturan komplikasyonları arasındadır $(9,16,21,22)$.

Video Yardımlı Torakoskopi (Video Asisted Thoracoscopy / VATS) son y1llarda popüler olup özellikle fibrinolitik ajanlar ile kullanılması ile tüp torakostominin yerini almıştır (4). Ancak torakoskopik debridman, anestezi altında yapılan cerrahi bir işlemdir ve işlem sonrası genellikle kan replasmanı gereksinimi olması ve pahalı olması dezavantajdır $(4,16)$. Bronkoplevral fistül gibi ciddi komplikasyonları da mevcuttur (21). Bu nedenlerle fibrinolitik ajanların tüp ile uygulanması VATS'ın ise açık torakotomiye alternatif olarak düşünülmesi gerektiğini öneren yayınlar da mevcuttur (9). Açık torakotomi ise, diğer tüm yöntemlerin yetersiz kaldığ1 organizasyon devresindeki olgularda uygulanabilir. VATS'ın yaygınlaşması ile kozmetik nedenler, yüksek fiyat, hastane yatış süresinin uzaması gibi nedenlerle açık cerrahi artık nadiren uygulanmaktadir $(4,16)$.

Bu sınırlı seride birden fazla cerrahın çalıştığ bir kamu hastanesinde, tek bir cerrahın kapa11 toraks drenajı ile takip ettiği post pnömonik ampiyemlerin teşhis, tedavi yaklaşımı sonuçları ile sunulmuştur. $\mathrm{Bu}$ nedenle istatistiki olarak anlamlı olmasa da vaka sayıları literatür ile uyumlu olarak yıllar içinde aşı programlarının uygulanması, toplumun genel refah düzeyinin artması, sağlık birimlerine daha fazla ulaşılabilirlik nedenleri ile yıllar içinde azalmış olmakla beraber 1999 ve 2002 y1llarında iki kez toplumsal kaynaklı pnömonilerin artmasına paralel olarak artış göstermiştir.

Sonuç olarak, çocukluk çağında pnömoniye bağlı gelişen ampiyemlerin tedavisinde klasik teşhis ve tedavi yöntemleri; sistemik antibiyotikler, kapalı interkostal gögüs tüpü drenajı ve gögüs fizyoterapisi halen etkin temel tedavidir. Uygulanan cerrahi ve anesteziye ait riskler, komplikasyon ve fiyat açısından değerlendirildiğinde; fibrinolitik tedavi ve açık torakotomi veya VATS ile yapılan debridman, dekortikasyon gibi girişimlerinin ampiyemde öncelikli tedavi yöntemleri olmadığı görülmektedir. 


\section{$K A Y N A K L A R$}

1. Kosloske AM. Infections of the Lungs, Pleura and madiastineum. In Welch KJ, Randolph JG, Ravitch MM, O'Neill JA and Rowe MI, editors. Pediatric Surgery, 4 th ed. Chicago, Year Book Medical Publishers, 1986; pp 657-673.

2. Grewal H, Smith SD. Lung infections: Lung Biopsy, Lung abscess, Bronchiectasis and Empyema. In Ziegler MM, Azizkhan $R G$, JG, and Weber TR: Operative Pediatric Surgery. McGraw-Hill, 2003; pp 455-463.

3. Celayir AC, Inalhan $M$, Etker Ş, Inan S. Çocuklarda infeksiyona sekonder plevral effuzyonlara yaklaşım: 6 yıllık deneyim. Cerrahpaşa Tip Dergisi 2000; 31(4): 191-195

4. Dorman RM, Vali K, Rothstein DH. Trends in treatment of infectious parapnömonic effusions in U.S. children's hospitals, 2004-2014. J of Pediatric Surgery 2016; (51):885-890.

5. Mahon C, Walker W, Drage A, Best E. Incidence, aetiology and outcome of pleural empyema and parapnömonic effusion from 1998 to 2012 in a population of New Zealand children. $J$ Paediatr Child Health 2016; 52(6): 662-668.

6. Proesmans M, Gijsens B, Van de Wijdeven P, De Caluwe H, Verhaegen J, Lagrou K et al. Clinical outcome of parapnömonic empyema in children treated according to a standardized medical treatment. Eur J Pediatr 2014; 173:1339-45.

7. Zampoli M, Zar HJ. Empyema and parapneumonic effusions in children: an update, South African Journal of Child Health 2007; 1(3): 121-128.

8. Johnson B, Rylander M, Beres AL. Do X-rays after chest tube removal change patient management?, J Pediatr Surg 2017; doi:10.1016/j.jpedsurg.2017.01.047.

9. Zampoli M, Chaya S, Zar HJ. Empyema in Children: Update of Aetiology, Diagnosis and Management Approaches, Curr Pulmonol Rep 2017; 6:16-25.

10. Telander RL, Moir CR. Acquired lesions of the lung and pleura. In Ashcraft KW, Holder TM Pediatric Surgery. W.B. Saunders Company 1993; pp 188-203.

11. Мiu T-Y. An overview of childhood empyema, Journal of Paediatric Respirology and Critical Care 2007; 3(2): 9-14.
12. Tsujimoto N, Saraya T, Light RW, Tsukahara Y, Koide T, Kurai D, et al. A Simple Method for Differentiating Complicated Parapnomonic Effusion/Empyema from Parapnomonic Effusion Using the Split Pleura Sign and the Amount of Pleural Effusion on Thoracic CT. PLoS One 2015;10(6): 1-12.

13. Light RW. Parapnömonic effusions and empyema. Clin Chest Med 1985;6(1): 55-62.

14. Quinn T, Alam N, Aminazad A, Marshall MB, Choong CKC. Decision making and algorithm for the management of pleural effusions. Thorac Surg Clin 2013; 23: 11-16.

15. Celayir A, Sümer B, Özgüver AA, Gültekin E, Inalhan M, Inan S. Ampiyem sonrası bir plevral kalınlaşma olgusu: cerrahi gerekli mi? Zeynep Kamil Tıp Bülteni 1997; 29(3-4): 218-221.

16. Divarcı E, Özcan C. Torasik ampiyeme minimal invazifyaklaşım. Çocuk Cerrahisi Dergisi 2016; 30(3): 236-241.

17. Kleinerman RA. Cancer risks following diagnostic and therapeutic radiation exposure in children. Pediatr Radiol 2006; 36(2): 121-125.

18. Raffensperger JG. Diseases of the pleura. In:Swenson's Pediatric Surgery 5th ed. Appleton \& Lange; 1990; 84:737-741.

19. Numanoğlu I. Akciğerler, In: Çocuk Cerrahisi, Ege Üniversitesi Tip Fakültesi Yayınları 1983: pp 991-1025.

20. James CA, Braswell LE, Pezeshkmehr AH, Roberson PK, Parks JA, Moore MB. Stratifying fibrinolytic dosing in pediatric parapnomonic effusion based on ultrasound grade correlation. Pediatric Radiology 2017; 47:89-95.

21. Marhuenda C, Barceló C, Fuentes I, Guillén G, Cano I, López $M$ et al. Urokinase versus VATS for treatment of empyema: a randomized multicenter clinical trial. Pediatrics 2014; 134(5):1301-1307.

22. Cha LM-J, Choi S, Kim T, Yoon SW. Intrapleural urokinase therapy in a neonate with pleural empyema. Pediatrics International 2016; 58:616-619. 